\title{
PERANAN SISTEM INFORMASI AKUNTANSI TERHADAP PERKEMBANGAN USAHA MIKRO, KECIL, DAN MENENGAH "RUMAH KREATIF BUMN" PURBALINGGA
}

\author{
Esti Saraswati $^{1}$, Riza Rizqiyah ${ }^{2}$, Irawan Randikaparsa ${ }^{3}$ \\ ${ }^{1}$ Program Studi S1 Akuntansi, Fakultas Ilmu Sosial, Universitas Harapan Bangsa \\ ${ }^{2,3}$ Program Studi S1 Manajemen, Fakultas Ilmu Sosial, Universitas Harapan Bangsa \\ E-mail : esti.saraswati1989@gmail.com
}

\begin{abstract}
Micro, Small and Medium Enterprises (MSMEs) are described as a sector that has a very important role in development in Indonesia. In Micro, Small and Medium Enterprises (MSMEs), it is necessary to continuously empower and develop them by trying to reduce the obstacles experienced by Micro, Small and Medium Enterprises (MSMEs), so that they can contribute more optimally to improving the welfare of the community. The majority of problems experienced by MSME players are not being able to separate between personal and business financial records and the low understanding of financial statement analysis so that accounting skills are needed to overcome this. The role of the Accounting Information System for small and medium enterprises (SMEs) is almost the same as that applied to large types of businesses. The role of the Accounting Information System can be used as a basis for reliable decision making in Micro, Small and Medium Enterprises (MSMEs) activities. Among others, decisions on market development, pricing, preparation of financial reports in accordance with accounting standards, and others. With the availability of appropriate financial records and based on the application of an accounting information system, it can make it easier for MSME players to access financing both from the government and creditors (banks) for business development. The purpose of this community service is to provide basic knowledge about accounting information systems so that the financial management of Micro, Small and Medium Enterprises (MSMEs) is getting better.
\end{abstract}

Keywords : Micro, Small and Medium Enterprises (MSMEs), Accounting Information, Accounting Information System.

\section{Abstrak}

Usaha Mikro, Kecil, dan Menengah (UMKM) digambarkan sebagai sektor yang mempunyai peranan yang sangat penting dalam pembangunan di Indonesia. Pada Usaha Mikro, Kecil, dan Menengah (UMKM) perlu dilakukan pemberdayaan dan dikembangkan secara terus menerus dengan berusaha mengurangi kendala yang dialami Usaha Mikro, Kecil, dan Menengah (UMKM), sehingga mampu memberi kontribusi lebih maksimal terhadap peningkatan kesejahteraan masyarakat. Mayoritas permasalahan yang dialami oleh pelaku UMKM adalah belum dapat memisahkan antara catatan keuangan pribadi dan bisnis dan masih rendahnya pemahaman akan analisis laporan keuangan sehingga dibutuhkan keterampilan akuntansi untuk mengatasi hal tersebut. Peranan Sistem Informasi Akuntansi untuk usaha kecil menengah (UKM) tidak jauh berbeda dengan yang sudah diaplikasikan pada perusahaan - perusahaan besar. Peranan Sistem Informasi Akuntansi bisa dijadikan dasar untuk pengambilan keputusan yang bisa diandalkan dalam kegiatan Usaha Mikro, Kecil, dan Menengah (UMKM). Penerapan Sistem Informasi Akuntansi memudahkan pelaku bisnis dalam pengambilan keputusan pengembangan pasar, penetapan harga, penyusunan laporan keuangan sesuai standar akuntansi, dan lain sebagainya. Dengan tersedianya pencatatan keuangan yang sesuai dan dilandasi penerapan sistem informasi akuntansi dapat memudahkan para pelaku UMKM untuk mengakses pembiayaan baik yang bersumber dari pemerintah maupun pihak kreditur (Bank) untuk perkembangan bisnisnya. Tujuan pengabdian kepada masyarakat ini untuk memberikan pengetahuan dasar mengenai sistem informasi akuntansi agar manajemen keuangan para pelaku Usaha Mikro, Kecil, dan Menengah (UMKM) semakin baik. 
Kata Kunci : Usaha Mikro, Kecil, dan Menengah (UMKM), Informasi Akuntansi, Sistem Informasi Akuntansi

\section{PENDAHULUAN}

Potensi UMKM di Indonesia dapat menjadi motor penggerak ekonomi bangsa, tetapi kurangnya sosialisasi menjadikan kurangnya pemahaman akan melakukan pengelolaan usaha dengan baik. Masalah yang kerap sering dijumpai pada pelaku UMKM adalah dimana sumber daya manusia UMKM di Indonesia belum bisa mengaplikasikan multiskill dalam pengelolaan usahanya seperti dalam hal manajemen, keuangan, marketing, serta teknologi. Pemicu inilah yang kerap membuat UMKM di Indonesia tidak bisa bertahan lama dan gagal bersaing dengan competitor yang sudah lebih stabil. Kendala yang kerap sering dialami oleh pelaku UMKM adalah terkait hal pengelolaan keuangan serta penguasaan teknologi yang belum menjadi perhatian utama bagi pelaku UMKM itu sendiri, yang dimana hal-hal itu penting dalam rangka penerapan sistem akuntansi UMKM.

Penerapan Akuntansi pada kegiatan bisnis di kalangan UMKM masih dirasa banyak merasakan kesulitan, pemicunya diantaranya keterbatasan sumber daya manusia, kemampuan sumber daya manusia dalam mengelola keuangan pada UMKM, serta belum adanya pedoman atau buku avuan yang dapat digunakan referensi untuk pengelolaan keuangan pada UMKM (Junaidi, 2017). Informasi keuangan UMKM yang sederhana yang dibuat oleh pelaku UMKM selama periode tertentu akan menghasilkan sebuah laporan keuangan. Untuk membuat laporan keuangan yang sesuai dengan prinsip dan standar akuntansi bukan hal yang mudah. Hal ini yang membuat para pelaku UMKM banyak yang melupakan membuat laporan keuangan yang sesuai standar dan prinsip-prinsip akuntansi yang berlaku. Pembukuan bukan dikhususkan hanya digunakan oleh perusahaan yang telah besar namanya atau telah maju saja. Akan tetapi, pembukuan juga wajib digunakan oleh usahaberskala kecil dan menengah atau bisa disebut dengan UKM (Suhendar \& Suhardi, 2018) Seiring berkembangnya usaha, maka sistem pembukuan dan akuntansi pun harus mengalami perkembangan. Terlebih pada saat jumlah transaksi pada usaha semakin meningkat dan akan menyulitkan jika dikerjakan secara manual, disinilah penerapan penggunaan teknologi sangat diperlukan, maka dari itu peran komputerisasi harus dilakukan dan diterapkan dalam akuntansi.

Penggunaan teknologi ditujukan untuk mencegah dan meminimalisasi kesalahan dalam penginputan data transaksi masuk dan keluar, sehingga para pelaku UMKM dapat memantau perkembangan usaha setiap saat serta dapat mengambil keputusan bisnis secara tepat dan cepat. Perwujudan Sistem Informasi dalam menghasilkan informasi keuangan bisa diwujudkan lewat teknologi akuntansi yang dapat digunakan oleh pihak-pihak berkepentingan dalam menilai kondisi perusahaan lewat siklus akuntansi yang tersaji pada laporan keuangan (Rudianto, 2012)

Pembuatan laporan keuangan perusahaan merupakan hal yang wajib dilakukan oleh para pelaku yang bergerak dalam dunia usaha. Pencatatan keuangan bisa dikelola dengan baik dengan cara mencatat semua aktivitas keuangan yang terjadi pada siklus suatu usaha. Laporan keuangan perusahaan didefinisikan sebagai kumpulan laporan yang menyajikan informasi mengenai aktivitas keuangan perusahaan, diantaranya mencakup laporan laba rugi, laporan kepemilikan modal, laporan arus kas, laporan posisi keuangan, dan juga catatan mengenai laporan keuangan tersebut. Laporan keuangan perusahaan merupakan gambaran mengenai serangkaian aktivitas keuangan yang berlangsung pada sebuah perusahaan. Dalam hal ini, setiap aktivitas yang terjadi tersebut dicatat berdasar pos- pos laporan keuangan yang sesuai dengan jenis aktivitas tersebut (Bachmid, 2017) 
Informasi Akuntansi bisa dijadikan dasar untuk pengambilan keputusan yang bisa diandalkan dalam kegiatan Usaha Mikro, Kecil, dan Menengah (UMKM). Penerapan Sistem Informasi Akuntansi memudahkan pelaku bisnis dalam pengambilan keputusan pengembangan pasar, penetapan harga, penyusunan laporan keuangan sesuai standar akuntansi, dan lain sebagainya. Penyediaan akan informasi akuntansi pun dipelukan dalam kaitannya antara hubungan usaha kecil dengan pemerintah dan pihak kreditur (Bank) (Pinasti, 2007). Informasi Akuntansi dipandang berpotensi dalam memberikan kontribusi dalam perencanaan, pengawasan, pengendalian dan pengambilan keputusan dalam berbagai kegiatan usaha, maka para pelaku UKM pun dituntut untuk dapat menerapkan informasi akuntansi agar memiliki kemampuan analisis dalam kegiatannya usahanya (Lestanti, 2015). Undang - Undang UKM No.9 Tahun 1995 dan Undang - Undang Perpajakan No. 2 Tahun 2007 tentang Pengembangan Usaha Kecil Menengah dan Koperasi didalamnya memuat dan menegaskan pentingnya dalam hal pencatatan dan penyelenggaraan informasi akuntansi pada sektor Usaha Kecil Menengah (UKM) (Sitoresmi, 2013).

Kementerian BUMN dengan Perusahaan Milik Negara bersinergi membangun "Rumah BUMN" dalam rangka memberikan wadah bagi para pelaku usaha mikro, kecil, dan menengah untuk belajar Bersama dan tentunya melakukan pembinaan terhadap pelaku UMKM agar menjadi Pelaku UMKM Indonesia yang mempunyai kualitas, dan mampu bersaing. Berdasarkan analisis situasi, maka dapat disimpulkan bahwa permasalahan mitra diantaranya banyak pelaku UMKM belum mengetahui dan paham bagaimana pencatatan dan pelaporan keuangan yang tertib dan teratur dan dipicu oleh tidak adanya sistem informasi akuntansi yang baik dan benar untuk mengawali disusunnya suatu laporan keuangan yang baik. Tujuan pengabdian kepada masyarakat ini untuk memberikan pengetahuan dasar mengenai sistem informasi akuntansi agar manajemen keuangan para pelaku UMKM "Rumah Kreatif BUMN" Purbalingga semakin baik.

\section{METODE PELAKSANAAN}

\section{A. Pra Kegiatan}

Prosedur yang dilakukan untuk mewujudkan tujuan dari Program pelaksanaan Pengabdian Kepada Masyarakat di UMKM "Rumah Kreatif BUMN" Purbalingga antara lain:

1. Melakukan observasi dan wawancara terhadap mitra mengenai permasalahan yang dihadapi oleh UMKM "Rumah Kreatif BUMN" Purbalingga.

2. Identifikasi masalah melalui wawancara dengan pengelola UMKM dan Narasumber yang berkompeten untuk memperoleh data dan solusi yang tepat guna penyelesaian masalah.

3. Penyusunan solusi permasalahan melalui studi literasi dan penelusuran regulasi untuk mencari ketentuan hukum yang dapat dimanfaatkan untuk mempermudah implementasi kegiatan pengabdian kepada masyarakat.

4. Kegiatan Pengabdian Kepada Masyarakat selanjutnya UMKM "Rumah Kreatif BUMN" Purbalingga, yang dilakukan melalui:

a. Penyuluhan penggunaan informasi akuntansi Pada UMKM "Rumah Kreatif BUMN" Purbalingga.

b. Melaksanakan kerjasama lanjutan berupa pendampingan kepada mitra untuk dapat meningkatkan produktivitas dan profitabilitas UMKM "Rumah Kreatif BUMN" Purbalingga. 
Empowerment : Jurnal Pengabdian Masyarakat, e-ISSN 2598-2052

Vol. 04 Nomor 01. 2021.26-33.

\section{B. Pelaksanaan}

\begin{tabular}{|l|l|}
\hline Jenis Kegiatan & $\begin{array}{l}\text { Workshop Peran sistem informasi akuntansi terhadap } \\
\text { perkembangan UMKM Rumah Kreatif BUMN Purbalingga. }\end{array}$ \\
\hline Pendaftaran & Riza Rizqiyah S.M., MBA. dan Mahasiswa \\
\hline MC & Irawan Randikaparsa S.E., MBA. \\
\hline Sambutan & $\begin{array}{l}\text { 1. Alfizi, S.E., MM. (Dekan FIS) } \\
\text { 2. Istriyati (Sekdin Diskopukm Purbalingga) }\end{array}$ \\
\hline Pemateri & $\begin{array}{l}\text { Esti Saraswati, S.E., M.Si } \\
\text { (Peran Sistem Informasi Akuntansi Terhadap Perkembangan } \\
\text { UMKM Rumah Kreatif BUMN Purbalingga) }\end{array}$ \\
\hline
\end{tabular}

1. Workshop Peran Sistem Informasi Akuntansi Terhadap Perkembangan UMKM "Rumah Kreatif BUMN" Purbalingga.

Materi Workshop yang disampaikan meliputi :

a. Kendala - Kendala yang dialami para pelaku UMKM

b. Kendala Pengelolaan Keuangan \& Penguasaan Teknologi

c. Kendala Keterbatasan Modal

d. Pengenalan Sistem Informasi Akuntasi \& Akuntansi Sederhana

e. Metode Akuntansi : Basis Akrual VS Basis Kas

f. Pengenalan awal contoh software akuntansi

2. Melaksanakan kerjasama lanjutan berupa pendampingan kepada mitra untuk dapat meningkatkan produktivitas dan profitabilitas UMKM di Purbalingga.

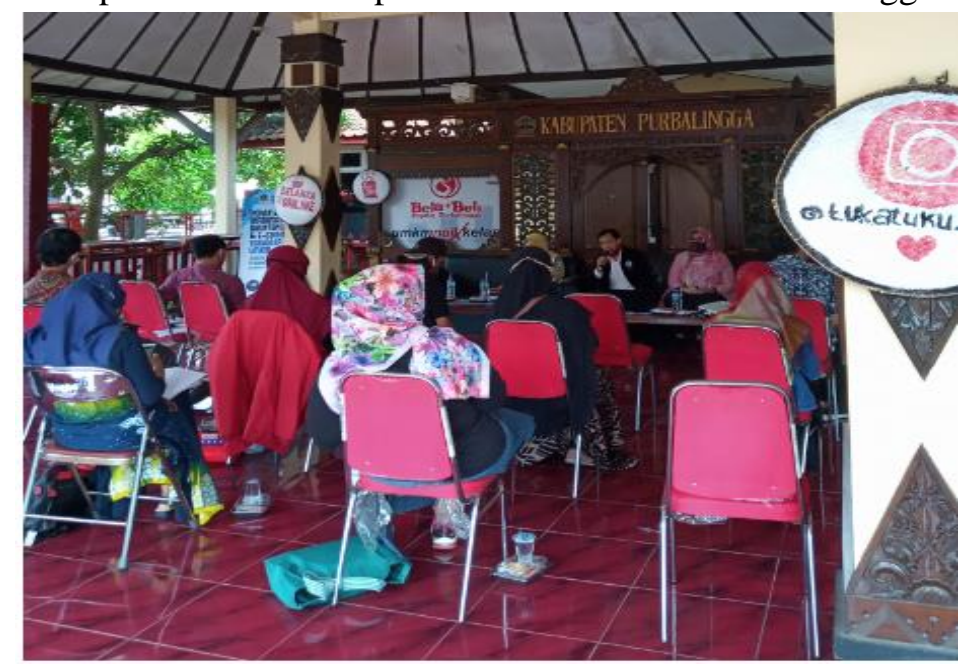

Gambar 1. Sambutan Dekan FIS Universitas Harapan Bangsa 


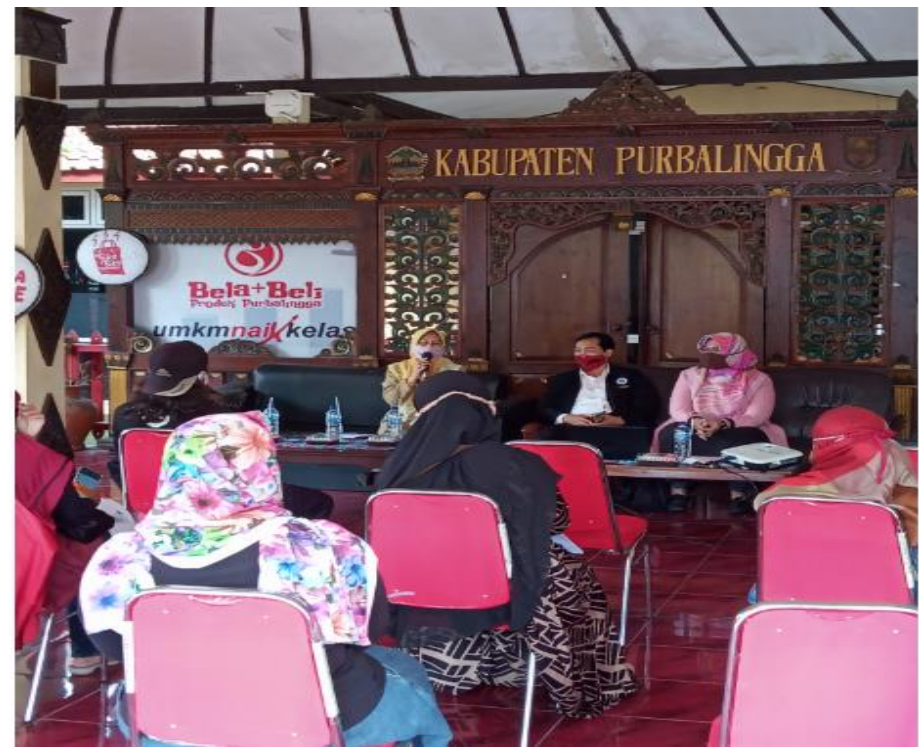

Gambar 2. Sambutan Sekdin Diskopukm Purbalingga
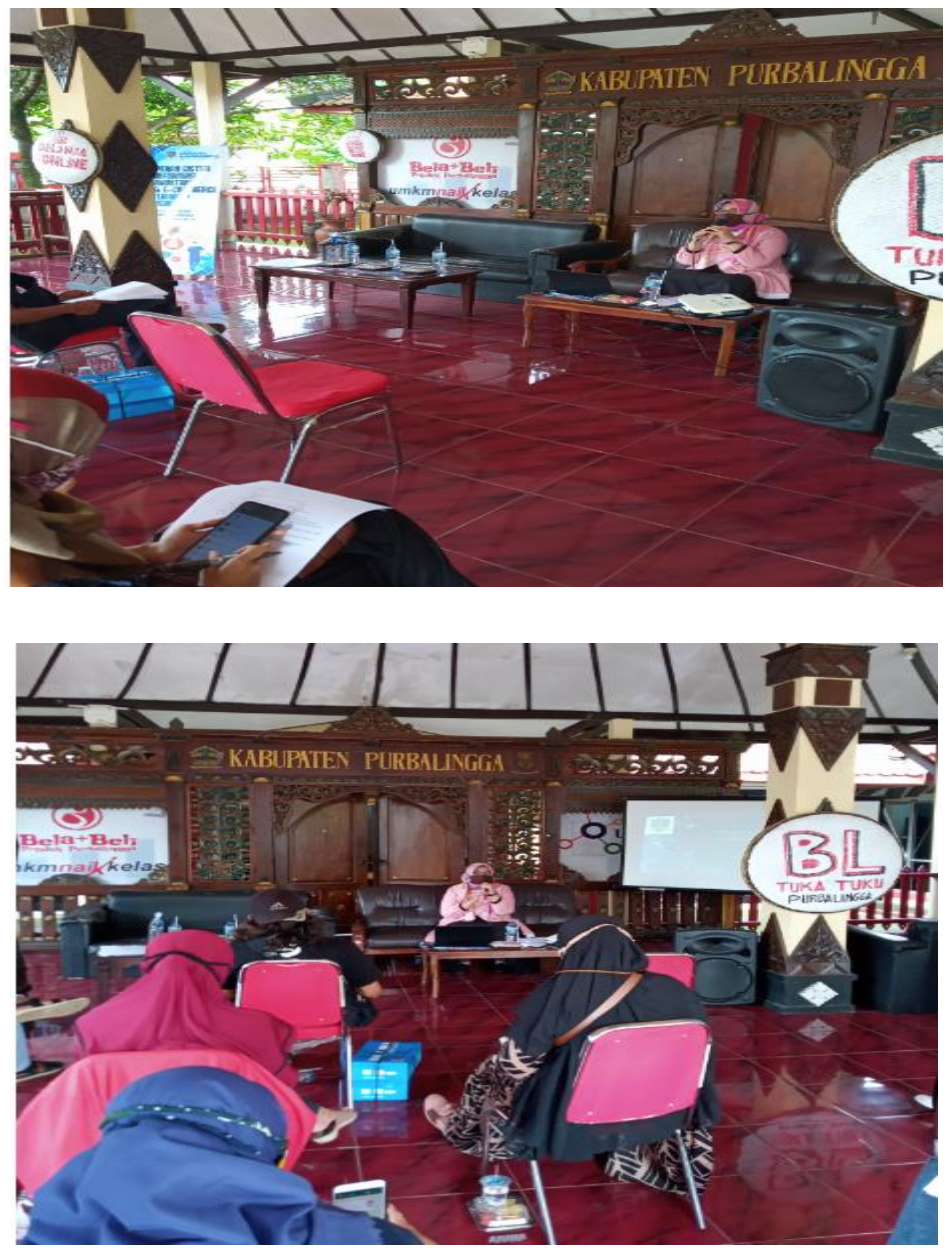

Gambar 3. Penyampaian Materi WorkshopPeran Sistem Informasi Akuntansi Terhadap Perkembangan UMKM Rumah Kreatif BUMN Purbalingga. 

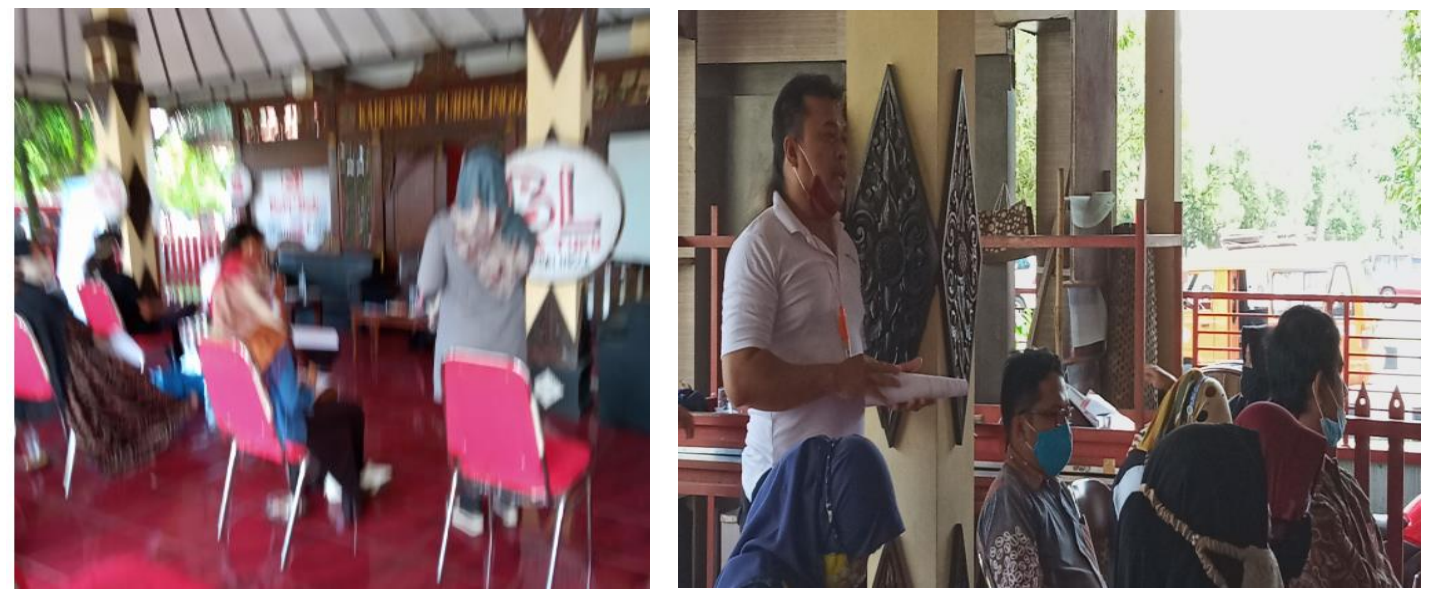

Gambar 4. Tanya Jawab/ Diskusi Seputar Materi Workshop

\section{HASIL DAN PEMBAHASAN}

a. Pelaksanaan Workshop pada hari Selasa, 29 Desember 2020 bertempat di Griya UMKM Kab. Purbalingga.

b. Total peserta yang hadir \pm 15 Orang (due to covid 19 ).

Berdasarkan Workshop "Peran Sistem Informasi Akuntansi Terhadap Perkembangan UMKM "Rumah Kreatif BUMN" Purbalingga yang telah tim pengabdi lakukan pada UMKM "Rumah Kreatif BUMN" Purbalingga, benar-benar diharapkan dapat memberikan dampak yang positif kepada para masyarakat setempat dan juga kepada tim pengabdi yang melakukan pelatihan/pembinaan tersebut, atau secara rinci hasil yang dicapai dari pelaksanaan pemberdayaan tersebut dapat diuraikan antara lain adalah sebagai berikut:

1. Peserta mendapatkan ilmu dan pengetahuan dasar mengenai penyusunan laporan keuangan sederhana pada UMKM.

2. Peserta mendapatkan ilmu dan pengetahuan mengenai Peran Sistem Informasi Akuntansi bagi perkembangan UMKM.

3. Peserta memahami dan memiliki pengetahuan dasar mengenai contoh software akuntansi untuk pencatatan keuangan yang lebih baik.

4. Ketertarikan dan rasa antusias peserta akan keingintahuan mengenai penggunaan software akuntansi untuk pencatatan laporan keuangan yang lebih baik.

Setelah pelaksanaan Workshop selesai dilaksanakan, maka penting untuk direncanakan keberlanjutan dari program Workshop tersebut. Keberlanjutan program di lapangan setelah kegiatan pengabdian kepada masyarakat ini selesai dilaksanakan adalah memonitoring penyusunan laporan keuangan maupun pembukuan yang sederhana yang sudah dilakukan oleh mitra.

\section{SIMPULAN}

Secara umum, setelah adanya tanya jawab/diskusi pada workshop, bahwa penggiat UMKM Rumah Kreatif BUMN Purbalingga sudah melakukan pencatatan laporan keuangan sederhana setiap harinya pada kegiatan bisnisnya, tetapi mayoritas belum sesuai dengan kaidah akuntansi serta banyak yang belum mengetahui terkait contoh software akuntansi yang berguna dan memudahkan dalam pencatatan laporan keuangan. 
Penerapan Sistem Informasi Akuntansi pada UMKM memang sudah seharusnya dilakukan. Hal ini untuk memudahkan pelaku UMKM mendapatkan dana segar, seperti pembiayaan usaha dari pemerintah melalui Bank atau mendapatkan investor. Pemerintah dan investor umumnya selalu meminta Laporan Keuangan UMKM, tanpa adanya laporan tersebut, maka akan sangat sulit untuk mendapatkan dana segar untuk mengembangkan usaha para pelaku UMKM.

Informasi akuntansi mempunyai manfaat terhadap perkembangan UMKM, diantaranya: untuk pengambilan keputusan, mengetahui naik turunnya laba usaha, mengetahui pemasukan dan pengeluaran uang serta untuk mengetahui grafik penjualan dan produksi dari pelaku UMKM. Pengenalan dan pelatihan mengenai akuntansi dapat menjadi wadah untuk mengembangkan UMKM lebih baik dan lebih maju lagi dalam bidang pengelolaan keuangan.

\section{SARAN}

1. Pelaku Usaha Mikro Kecil dan Menengah perlu menambah ilmu tentang akuntansi dengan cara mengikuti pelatihan baik yang berbayar maupun yang tidak berbayar. Pemerintah telah banyak memfasilitasi para Usaha Mikro Kecil dan Menengah untuk memberikan berbagai pelatihan- pelatihan diantaranya Manajemen Keuangan yang sangat diperlukan untuk perkembangan Usaha Mikro Kecil dan Menengah

2. Pelaku Usaha Mikro Kecil dan Menengah agar memperhatikan pencatatan keuangan yang berpedoman pada akuntansi agar dapat memberikan manfaat untuk perkembangan usahanya, dan bentuk perhatian pemerintah kepada UMKM dalam rangka memudahkan UMKM dalam membuat dan menyajikan Laporan Keuangan adalah telah meluncurkan Aplikasi pencatatan keuangan "Lamikro". Maka dari itu, para pelaku UMKM bisa memaksimalkan dalam memanfaatkan Aplikasi pencatatan keuangan tidak berbayar yang sudah diluncurkan oleh pemerintah.

\section{UCAPAN TERIMA KASIH}

Penulis mengucapkan terima kasih kepada LPPM Universitas Hapan Bangsa, Rektor Universitas Harapan Bangsa, Dekan FIS Universitas Harapan Bangsa, DISKOPUKM Purbalingga, Sekdin DISKOPUKM Purbalingga, Pelaku UMKM "Rumah Kreatif BUMN" Purbalingga, dan semua pihak untuk segala dukungan yang telah diberikan sehingga kegiatan pengabdian kepada masyarakat ini dapat terselenggara dengan baik.

\section{DAFTAR PUSTAKA}

Bachmid, Said, F. (2017). Pelatihan Akuntansi Berbasis Sistem Informasi Akuntansi. Dharma Bhakti Ekuitas, 01(02), 26-32. Retrieved from http://repository.ekuitas.ac.id/bitstream/handle/123456789/331/JR00055 - Faiz Said Bachmid.pdf? sequence $=2 \&$ isAllowed $=y$

Junaidi, J. (2017). Pelatihan Manajemen Keuangan sebagai Upaya Peningkatan Daya Saing UMKM dalam Menghadapi MEA di Kecamatan Tomoni Kabupaten Luwu Timur. RESONA: Jurnal Ilmiah Pengabdian Masyarakat, $1(1), \quad 46-51$. https://doi.org/10.35906/jipm01.v1i1.238

Lestanti, D. (2015). Pengaruh Pengetahuan Akuntansi, Pengalaman Usaha, dan Motivasi Kerja terhadap Persepsi Penggunaan Informasi Akuntansi pada Pelaku UMKM di Boyolali. Universitas Negeri Yogyakarta.

Pinasti, M. (2007). Pengaruh Penyelenggaraan dan Penggunaan Informasi Akuntansi Terhadap 
Persepsi Pengusaha Kecil atas Informasi Akuntansi: Suatu Riset Eksperimen. Simposium Nasional Akuntansi X Unhas Makassar, AMKP-09(26-28 Juli 2007), 1-21.

Rudianto. (2012). Pengantar Akuntansi. Jakarta: Erlangga.

Sitoresmi, L. D. (2013). Faktor-Faktor Yang Mempengaruhi Penggunaan ( Studi Pada Kub Sido Rukun Semarang ). Diponegoro Journal of Accounting, 2(2009), 1-13.

Suhendar, D., \& Suhardi, D. (2018). Optimalisasi Pengelolaan Usaha Kecil Menengah (Ukm) Kerupuk Dorokdok Desa Cibingbin Kecamatan Cibingbin, Kabupaten Kuningan. Empowerment: Jurnal Pengabdian Masyarakat, 1(02), 45-52. https://doi.org/10.25134/empowerment.v1i02.1573

\section{Peraturan Perundang- Undangan:}

Undang - Undang Usaha Kecil Menengah No.9 Tahun 1995

Undang - Undang Perpajakan No. 2 Tahun 2007 tentang Pengembangan Usaha Kecil Menengah dan Koperasi 